\title{
Heterogeneity of carboxyl-terminal parathyroid hormone circulating forms in patients with hyperparathyroidism due to end stage renal disease
}

\author{
Heterogeneidade das formas carboxi-terminal circulantes \\ de paratormônio em pacientes com hiperparatiroidismo \\ devido à insuficiência renal crônica terminal
}

José Gilberto H. Vieira', Ilda S. Kunii', Monique N. Ohe', Aluizio B. Carvalho²

' Disciplina de Endocrinologia, Departamento de Medicina, Escola Paulista de Medicina, Universidade Federal de São Paulo (Unifesp/ EPM), São Paulo, SP, Brasil 2 Disciplina de Nefrologia, Departamento de Medicina, Unifesp/EPM, São Paulo, SP, Brasil
Correspondence to: José Gilberto H. Vieira

Av. General Valdomiro de Lima, 508 04344-903 - São Paulo, SP, Brasil jose.vieira@fleury.com.br

Received on May/21/2009 Accepted on Aug/3/2009

\begin{abstract}
Objective: To study carboxyl-terminal $(\mathrm{COOH})$ parathyroid hormone (PTH) circulating forms in patients with hyperparathyroidism due to end stage renal disease (ESRD). Methods: An immunometric assay that recognizes both intact and $\mathrm{COOH}$ PTH forms was developed. The assay, in conjunction with an intact assay, was used to measure PTH in serum samples obtained from 25 patients with hyperparathyroidism due to ESRD. Samples were also submitted to gel filtration chromatography in a Superdex ${ }^{\circledR} 301.6 \times 60 \mathrm{~cm}$ column, and the PTH content in the elution tubes, measured using both assays. Results: Values from 39.000 to $232.300 \mathrm{ng} / \mathrm{mL}$ (mean $\pm \mathrm{sd}$ $=101.680 \pm 45.330 \mathrm{ng} / \mathrm{mL}$ ) were found using the $\mathrm{COOH}$ assay (PTH 39-84 was used as standard). Values obtained by the intact PTH assay ranged from 318 to $3.307 \mathrm{ng} / \mathrm{mL}(1.769 \pm 693 \mathrm{ng} / \mathrm{mL})$ with a correlation between assays of $0.462(p=0.02)$. The elution profile obtained using the $\mathrm{COOH}$ assay showed a preponderance of forms with MW ranging from 8.500 to 4.500 daltons. The profiles obtained from the 25 patients were very similar. Conclusions: In patients with hyperparathyroidism due to ESRD circulating PTH levels contain a broad range of molecular forms including $\mathrm{COOH}$ with $\mathrm{MW}$ ranging from 8.500 to 4.500 daltons. These forms are not recognized by the standard intact PTH assays. The correlation of these findings to the clinical aspects of bone disease in ESRD patients remains to be studied. Arq Bras Endocrinol Metab. 2009;53(9):1074-8

Keywords

PTH assays; carboxyl-terminal fragments of PTH, end-stage kidney disease; chromatography, gel
\end{abstract}

\section{RESUMO}

Objetivo: Estudar as formas carboxi-terminal ( $\mathrm{COOH}$ ) circulantes de paratormônio (PTH) em pacientes com hiperparatiroidismo devido à insuficiência renal crônica (IRC) terminal. Métodos: Foi desenvolvido um ensaio imunométrico que reconhece formas intactas e $\mathrm{COOH}$ longas de PTH. Esse ensaio foi utilizado, em conjunto com um ensaio para molécula intacta de PTH, em amostras de 25 pacientes com hiperparatiroidismo devido à IRC. As amostras também foram submetidas à cromatografia de gel filtração em coluna de Superdex ${ }^{\circledR} 30$ de $1,6 \times 60 \mathrm{~cm}$, e o conteúdo de PTH nos tubos de eluato foi medido, empregando-se os dois ensaios. Resultados: Valores entre $39.000 \mathrm{e}$ $232.300 \mathrm{ng} / \mathrm{mL}$ (média $\pm \mathrm{dp}=101,680 \pm 45,330 \mathrm{ng} / \mathrm{mL}$ ) foram obtidos usando-se o ensaio $\mathrm{COOH}$ (PTH 39-84 foi utilizado como padrão). Com o ensaio para PTH intacto, os valores distribuíramse entre 318 e 3,307 ng/mL $(1,769 \pm 693 \mathrm{ng} / \mathrm{mL})$ com correlação entre ambos de 0,462 $(p=0,02)$. $\mathrm{O}$ perfil cromatográfico obtido com o ensaio $\mathrm{COOH}$ mostrou predomínio de formas com PM entre 8.500 e 4.500 daltons. Os perfis cromatográficos dos 25 pacientes foram bastante semelhantes. Conclusões: Em pacientes com hiperparatiroidismo devido à IRC, os níveis circulantes de PTH contêm um espectro de formas moleculares que incluem formas carboxi-terminais, com PM entre 8.500 e 4.500 daltons. Essas formas não são reconhecidas pelos ensaios de rotina utilizados para a medida de PTH intacto. A correlação entre esses achados e os aspectos clínicos da doença óssea em pacientes com IRC necessita de maiores estudos. Arq Bras Endocrinol Metab. 2009;53(9):1074-8

Descritores

Ensaios para PTH; formas carboxi-terminais de PTH; insuficiência renal crônica; cromatografia em gel 


\section{INTRODUCTION}

Parathyroid hormone $(\mathrm{PTH})$ is a linear 84 amino acid peptide secreted by the parathyroid glands. The biological activity of PTH, defined by binding to the classical PTHI receptor (PTHIR), depends on the integrity of the amino-terminal sequence of the peptide, mainly its first four amino acids (1).

Methods for measuring circulating PTH have evolved significantly since the introduction of the first radioimmunoassay in $1963(2,3)$. Several competitive immunoassays were described during the 1970's and 1980's. Reference ranges as well as diagnostic sensitivity and specificity obtained with those assays were markedly different. The differences mirrored the wide spectrum of circulating forms of PTH recognized by the several polyclonal antibodies used in the competitive assays. With the description, in the late 1980's, of the so-called "second-generation non-competitive immunometric assays" ("sandwich"-type), supposedly measuring only "intact" PTH (sequence 1-84), there was a clear improvement of diagnostic sensitivity and specificity, as well as a better standardization of assay results (4).

Nonetheless, new studies suggested that, in some clinical circumstances, mainly in patients with end stage renal disease (ESRD), additional molecular forms, besides the sequence 1-84, were also measured by these intact PTH assays (5). Included were carboxyl-terminal $(\mathrm{COOH})$ fragments lacking only the first amino-terminal amino acids (e.g. peptide 7-84), also known as "long" $\mathrm{COOH}$ fragments. These forms are part of a broad spectrum of $\mathrm{COOH}$-terminal forms which includes the quantitatively more important shorter forms (not recognized by the second-generation assays), known to circulate in high concentration in patients with ESRD (6).

Later "third-generation" assays were introduced (7) based on the employment of amino-terminal specific antibodies with strict specificity for the first four amino acids of the PTH molecule. Consequently, they measure only the bioactive molecule, via PTHIR, PTH-(1-84). These observations brought the possibility that, mainly in patients with ESRD, results with better correlation to PTH action (via PTHIR) would be obtained with these third-generation assays (7). In patients with ESRD, the new assay could mean a more specific tool for measuring PTH action on bone cells, since, in these patients, PTH is used as a surrogate marker for metabolic bone disease. Some publications showed that this could indeed be the case, in special if one measures PTH using both second- and third-generation assays and use both results to calculate a relationship between the PTHIR active ((1-84)-PTH) and non-active ((784)-PTH) forms (8). In spite of all logic behind this approach, other publications, from several reference centers, showed that correlation between bone status and PTH measurements in patients with ESRD was similar using third- or second-generation assays $(9,10)$. The same observation stands for the 1-84/7-84 PTH ratio. Furthermore, correlation between PTH values obtained with third- and second-generation assays are good, even in patients with ESRD.

One important point concerning the physiological role of the $\mathrm{COOH}$-terminal PTH forms are the recent publications by the group of Bringhurst and cols. (11-13) showing that these peptides have biological actions that are independent of activation or blocking of PTHIR. More importantly, a putative C-PTH receptor can be activated by forms shorter than PTH-(7-84). These include PTH-(24-84) and, even, albeit with less affinity, PTH-(39-84). These findings can have important implications on the biological meaning of the third- and second-generation PTH ratio measurement in ESRD patients. Since second-generation assays are usually based on antibodies that recognize epitopes in the aminoterminal region that are not present in most of these $\mathrm{COOH}$-terminal PTH forms, they may be not measured by standard intact second-generation assays.

In this paper, we describe an immunofluorometric assay that recognizes an ample spectrum of $\mathrm{COOH}$ terminal forms of PTH. The levels of PTH found in patients with ESRD using the assay are compared with those obtained using an intact (second-generation) PTH assay. We also present the results obtained using both assays to measure PTH immunoreactivity in the eluate obtained by applying serum samples of ESRD patients to a gel filtration chromatography column.

\section{METHODS}

\section{Samples}

Twenty-five dialysis patients with ESRD submitted to parathyroidectomy in order to control severe hyperparathyroidism were studied. Blood samples were collected just prior to surgery and serum samples stored at $-20{ }^{\circ} \mathrm{C}$ until studied. The protocol was approved by the Ethics Committee of our institution (Escola Paulista de Medicina, Universidade Federal de São Paulo) and was part of a large study on surgical and parathyroid tissue autotransplantation optimization protocols. 


\section{$\mathrm{COOH}$ assay}

To measure $\mathrm{COOH}$-terminal forms of circulating $\mathrm{PTH}$, an immunofluorometric assay based on monoclonal and polyclonal antibodies was developed. The monoclonal antibody (H5P10) was produced by conventional fusion protocol based on mice immunized against synthetic human PTH-(53-84) and its specificity was directed against the region around amino acids 68-69 (14). The polyclonal antibody was developed in rabbits immunized against bovine PTH and had a broad specificity, including amino and $\mathrm{COOH}$-terminal regions of human PTH. In the assay design, the $\mathrm{COOH}$-terminal specific monoclonal antibody is adsorbed to a solid phase (microtiter plates, FluoroNunc ${ }^{\mathrm{TM}}$, Nunc, Roskield, Denmark) at $10 \mu \mathrm{g} / \mathrm{mL}$ in PBS, $20 \mathrm{mM}, \mathrm{pH} 7.4(200$ $\mu \mathrm{L} /$ well). After an overnight incubation at $4{ }^{\circ} \mathrm{C}$, the plates are washed and, in order to lower nonspecific binding, treated with $200 \mu \mathrm{L} /$ well of Tris $\mathrm{HCl} 50 \mathrm{mM}$ solution containing $0.5 \%$ bovine albumin and $0.05 \%$ bovine $\gamma$-globulin (assay buffer) for one hour at $37{ }^{\circ} \mathrm{C}$. After a new wash, the plates were ready for the assay.

As standard, synthetic hPTH-(39-84) (Bachem AG, Bubendorf, Switzerland) was used diluted in assay buffer with $2 \%$ mouse serum. Aliquots of $100 \mu \mathrm{L}$ of the standard samples (diluted 1:10 in assay buffer) or column eluate were added, together with $100 \mu \mathrm{L}$ of the rabbit polyclonal antibody in a 1:2000 dilution. After an overnight incubation followed by washing, $200 \mu \mathrm{L}$ of a 1:1 000 dilution of europium-labeled (Europium labeling kit, PerkinElmer, Turku, Finland) monoclonal anti-rabbit IgG antibody, produced at our laboratories, was added. After an additional a two-hour incubation, plates were washed and time-resolved fluorescence was read. The assay presented a sensitivity of $50 \mathrm{ng} / \mathrm{L}$ (hPTH-(39-84)), an inter-assay CV of less than $10 \%$, and a cross-reactivity (based on a $100 \%$ cross-reactivity with hPTH-(39-84)) of 52.8\% with hPTH-(7-84), $28.4 \%$ with hPTH-(1-84) and no cross-reactivity with the sequences 53-84, 44-68 and 69-84 of hPTH. The study of samples obtained from 30 adults with normal renal function showed values inferior to $500 \mathrm{ng} / \mathrm{L}$.

\section{Intact PTH assay}

A monoclonal antibody-based immunofluorometric assay developed at our laboratory was employed. The assay employed two monoclonal antibodies, one amino-terminal specific (labeled with europium) and one $\mathrm{COOH}-$ terminal specific (the same H5Pl0 used in the long $\mathrm{COOH}$ assay). The assay had an analytical sensitivity of
$3 \mathrm{ng} / \mathrm{L}$ and a cross-reactivity of 50\% with hPTH-(7-84) (PTH-(1-84) was used as reference). Upper normal range for serum PTH using this assay was $46 \mathrm{ng} / \mathrm{L}$ (15).

\section{Gel filtration chromatography}

Serum samples were submitted to gel filtration chromatography on a Hiload Superdex 30, 1.6 x $60 \mathrm{~cm}$ column coupled to a FPLC Akta system (GE Healthcare). The gel column was chosen due to its fractionation range (globular proteins) with $\mathrm{V} 0$ of $<10.000$ daltons. Serum samples of $0.5 \mathrm{~mL}$ were applied to the system, eluted $(1 \mathrm{~mL} / \mathrm{min})$ with a PBS $0.05 \mathrm{M}, \mathrm{pH} 7,2$, $0.15 \mathrm{M} \mathrm{NaCl}$ buffer and $1.0 \mathrm{~mL}$ aliquots were collected for PTH analysis using both assays. Column calibration included blue dextran (V0), synthetic human PTH-(184)(MW 9425 ) was measured using the intact PTH assay, and synthetic human PTH-(39-84)(MW 4 962) was measured using the $\mathrm{COOH}$ immunometric assay. $\mathrm{PTH}$ measurement using the $\mathrm{COOH}$ and intact assays were performed in tubes number 40 to number 70 in all chromatographies. These tubes were chosen after calibration studies, and results of pilot serum samples (from patients with secondary hyperparathyroidism due to ESRD) indicated that they included all PTH forms detectable by both assays.

\section{RESULTS}

\section{Correlation between serum values of intact and COOH-terminal PTH assays}

PTH values in serum samples from the 25 patients with ESRD ranged from 318 to $3.307 \mathrm{ng} / \mathrm{L}$ (mean $\pm \mathrm{sd}$ : 1,769 $\pm 693 \mathrm{ng} / \mathrm{L}$ ) using the intact assay and from 39,000 to $232,300 \mathrm{ng} / \mathrm{L}(101,680 \pm 45,330 \mathrm{ng} / \mathrm{L})$ using the $\mathrm{COOH}$ assay. The coefficient of correlation (Pearson's $\mathrm{r}$ ) between the values obtained with the two methods was $0.462(\mathrm{p}=0.02)$. Data are presented in figure 1 .

\section{Chromatography results}

In figure 2, the chromatography profile obtained with the serum of one representative patient with intact PTH of $1.389 \mathrm{ng} / \mathrm{L}$ and COOH-terminal PTH of $118.450 \mathrm{ng} / \mathrm{L}$ was depicted. In the left $\mathrm{Y}$-axis $(\mathrm{ng} / \mathrm{L})$, the $\mathrm{PTH}$ values measured in the eluate tubes, using both assays, are plotted. The void volume of the column (V0) as well as the elution of PTH-(1-84) (MW 9425 daltons) and PTH(39-84) (MW 4982 daltons) are indicated by arrows, and the scale of MW (daltons) represented in the right Y-scale. 


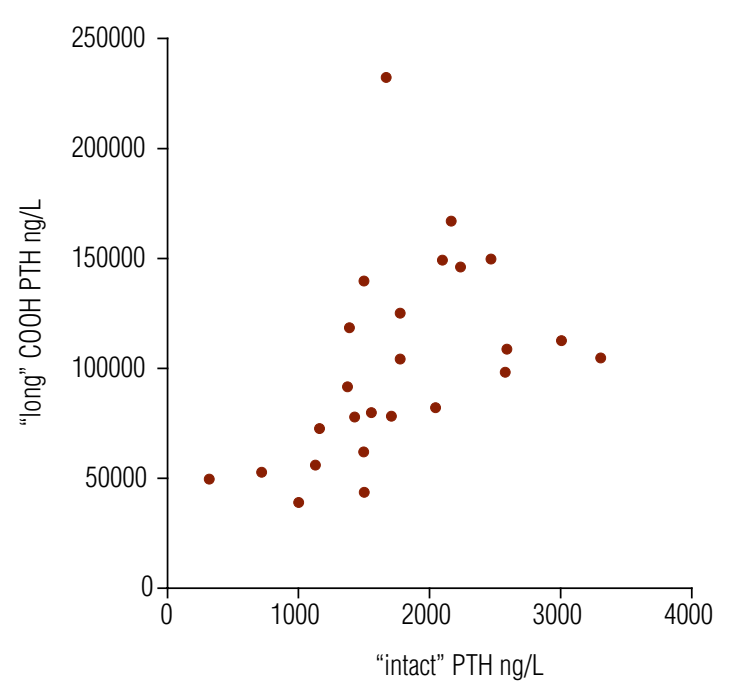

Figure 1. Correlation of values obtained $(n=25)$ from patients with ESRD using the long carboxyl-terminal ( $\mathrm{COOH})$ PTH assay and an intact PTH assay that recognizes predominantly PTH-(1-84) $(r=0.4619 ; p=0.02)$.

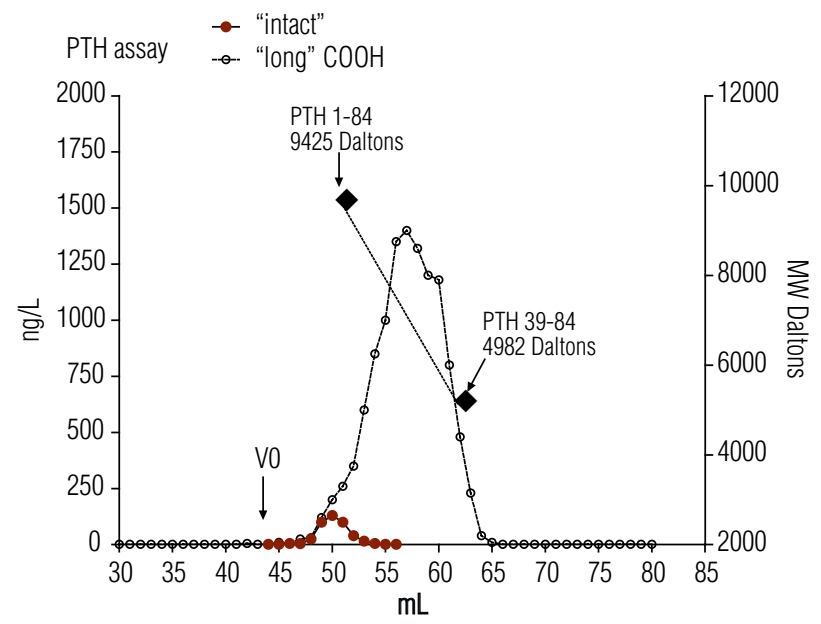

Figure 2. Elution profile of a serum sample from a patient with ESRD loaded on a Hiload Superdex $30^{\circledR} 1.6 \times 60$ column. PTH contained in the elution tubes was measured using the long carboxyl-terminal $(\mathrm{COOH})$ assay an intact PTH assay. The tubes which were blue dextran (V0), synthetic PTH-(1-84) (9425 daltons) and hPTH(39-84) (4982 daltons) eluted are also depicted.

All immunoreactive PTH measured with the intact assay appeared in tubes 45 to 55 , which is compatible with column calibration and assay specificity, since PTH (1-84) eluted with a peak around tube 50 , as seen in figure 2 . The elution of PTH forms detected with the $\mathrm{COOH}$ assay ranged from tube 45 to 65 , encompassing forms with molecular weight from 10,000 to 4,500 , according to the calibration profile. In order to evaluate the distribution of PTH forms recognized by the long $\mathrm{COOH}$ assay along the elution profile of the column, the elution profile obtained with the $\mathrm{COOH}$ assay was arbitrarily divided into four quartiles. The first one included tubes 45 to
50 ; the second, tubes 50 to 55 ; the third, from 55 to 60 ; and the fourth, from 60 to 65 . The percent (mean $\pm \mathrm{sd}$ ) quartile distribution in the 25 samples was $7.1 \pm 5.7$ for the first quartile; $30.5 \pm 10.8$ for the second; $51.0 \pm 11.1$ for the third; and $11.4 \pm 6.4$ for the forth. In accordance to the molecular weight distribution, the intact assay recognized only PTH eluted in the first and second quartiles, and the $\mathrm{COOH}$ assay forms with MW ranging from 10.000 to 4.500 daltons, included in the four quartiles, with higher values found in the third.

\section{DISCUSSION}

PTH in circulation is quite heterogenous, with forms encompassing the complete 1-84 peptide to small fragments consisting mainly of $\mathrm{COOH}$ sequences. These last ones are known to accumulate in patients with progressive degrees of renal failure since their metabolic clearance depends heavily on glomerular filtration. The possibility that PTH fragments lacking the aminoterminal sequence and, consequently, biological action via PTHRl can have some biological action is not new $(16,17)$. Experimental evidence of the presence of a $\mathrm{COOH}$ receptor is summing up $(18,19)$. The clinical importance of measurement of these $\mathrm{COOH}$ fragments is still not clear but is based mainly on data provided by intact PTH assays that measure, besides the 1-84 form, only molecular forms with small amino-terminal deletions, e.g. PTH (7-84) (20). The other methodological alternative is the use of old $\mathrm{COOH}$ specific competitive assays that measure almost all circulating forms, from the intact molecule to small $\mathrm{COOH}$ fragments (6).

In the setting of ESRD, the question is particularly complex and is still subject to research and controversy $(21,22)$. Our results confirm the presence of high levels of $\mathrm{COOH}$ fragments of significant molecular weight (> 4500 daltons) in serum samples obtained from patients with ESRD. These forms include the PTH 7-84 (MW 8781 daltons), but also include large quantities of $\mathrm{COOH}$ molecular form fragments, shorter than 7-84. One interesting observation is the profile of forms detected by the $\mathrm{COOH}$ assay running from intact PTH to forms around 4500 daltons. These $\mathrm{COOH} \mathrm{PTH}$ molecules have MW ranging from 8500 to 4500 and correspond to deletions of 10 to 40 amino acids. They are represented in the chromatographic system employed by forms eluting in the third and fourth quartiles. These peptides are not recognized by the second-generation intact assays, have no activity in the PTHIR, but bind to 
the C-PTH receptor with the same affinity of PTH-(1$84)$ and (7-84) (12). One additional point that must be taken into account in the analysis of the elution profile is the specificity of the assay developed that spans from $100 \%$ with PTH-(39-84) to $28 \%$ with PTH-(1-84).

The present findings are in accordance with those described by Zhang and cols. (23) in a recent publication, which used immunoaffinity and mass spectrometry to detect $\mathrm{COOH}$ fragments in samples from patients with ESRD. They described peptides ranging from 3484 to $45-84$ to be the most abundant. These forms are, at least in part, detected by our $\mathrm{COOH}$-specific assay. Methodological details could explain some potential differences in the detected forms, and can be related to the recognition of the antibodies used in the present assay or in the affinity purification used by Zhang and cols. (23).

The relative uniformity in the PTH-elution profile observed in the 25 patients with ESRD, confirmed by the low CV's of the percent distribution in the percentiles, indicate that it may be difficult to use this protocol to classify the bone disease presented by these patients. More studies correlating bone histomorphometry studies to PTH levels measured using assays like the one described here are necessary in order to define a potential clinical utility for the measurement of these long $\mathrm{COOH}$ terminal fragments of PTH in these patients.

Support: Fundação de Amparo à Pesquisa do Estado de São Paulo (Fapesp), grant 2003/14133-0

Disclosure: no potential conflict of interest relevant to this article was reported.

\section{REFERENCES}

1. Loveridge N, Dean V, Goltzman D, Hendy GN. Bioactivity of parathyroid hormone and parathyroid hormone-like peptide: agonist and antagonist activities of amino-terminal fragments as assessed by the cytochemical bioassay and in situ biochemistry. Endocrinology. 1991;128(4):1938-46.

2. Berson AS, Yaloow RS, Aurbach GD, Potts JT. Immunoassay of bovine and human parathyroid hormone. Proc Natl Acad Sci USA. 1963;49(5):613-6.

3. Vieira JGH, Kunii IS, Nishida SK. Evolution of PTH assays. Arq Bras Endocrinol Metabol. 2006;50(4):621-7.

4. Nussbaum SR, Zaharadnik RJ, Lavigne JR, Brennan GL, NozawaUng K, Kim L, et al. Highly sensitive two-site immunoradiometric assay of parathyrin, and its clinical utility in evaluating patients with hypercalcemia. Clin Chem. 1987;33(8):1364-7.

5. Quarles LD, Lobauch B, Murphy G. Intact parathyroid hormone over-estimates the presence and severity of parathyroid-mediated osseous abnormalities in uremia. J Clin Endocrinol Metab. 1992;75(1):143-50.

6. Brandão CM, Kasamatsu TS, Oliveira MA, Vieira JG. Circulating molecular forms of parathyroid hormone in primary and secondary hyperparathyroidism. Braz J Med Biol Res. 1989;22(8):963-5.
7. Brossard JH, Cloutier M, Roy L, Lepage R, Gascon-Barré $M$, D'Amour P. Accumulation of a non-(1-84) molecular form of parathyroid hormone (PTH) detected by intact PTH assay in renal failure: importance in the interpretation of PTH values. J Clin Endocrinol Metab. 1996;81(11):3923-9.

8. Monier-Faugere MC, Geng Z, Mawad H, Friedler RM, Gao $\mathrm{P}$ Cantor TL. Improved assessment of bone turnover by the PTH(1-84)/large C-PTH fragments ratio in ESRD patients. Kidney Int. 2001;60(4):1460-8.

9. Coen G, Bonucci E, Ballanti P, Balducci A, Calabria S, Nicolai GA, et al. PTH 1-84 and PTH "7-84" in the noninvasive diagnosis of renal bone disease. Am J Kidney Dis. 2002;40(2):348-54.

10. Salusky IB, Goodman WG, Kuizon BD, Lavigne JR, Zahranik RL, Gales $B$, et al. Similar predictive value of bone turnover using first- and second generation immunometric PTH assays in pediatric patients treated with peritoneal dialysis. Kidney Int. 2003;63(5):1801-8.

11. Divieti $P$, Inomata $N$, Chapin $K$, Singh $R$, Jüppner $H$, Bringhurst FR. Receptors for the carboxyl-terminal region of PTH (1-84) are highly expressed in osteocitic cells. Endocrinology. 2001;142(2):916-25.

12. Divieti P, Geller Al, Suliman G, Jüppner H, Bringhurst FR. Receptors specific for the carboxyl-terminal region of parathyroid hormone on bone-derived cells: determinants of ligand binding and bioactivity. Endocrinology. 2005;146(4):1863-70.

13. Murray TM, Rao LG, Divieti P, Bringhurst FR. Parathyroid hormone secretion and action: evidence for discrete receptors for carboxyl-terminal region and related biological actions of carboxylterminal ligands. Endocr Rev. 2005;26(1):78-113.

14. Vieira JG, Nishida SK, Kasamatsu TS, Amarante EC, Kunii IS. Development and clinical application of an immunofluorometric assay for intact parathyroid hormone. Braz J Med Biol Res. 1994;27(10):2379-82.

15. Vieira JG, Nishida SK, Camargo MT, Obara LH, Kunii IS, Ohe MN, et al. [Parathyroid hormone values obtained with immunometric assays depend on the amino-terminal antibody specificity]. Arq Bras Endocrinol Metab. 2004;48(4):518-24.

16. de Deuxchaisnes CN, Fisher JA, Dambacher MA, Devogelaer JP, Arber CE, Zanelli JM, et al. Dissociation of parathyroid hormone bioactivity in pseudohypoparathyroidism type I. J Clin Endocrinol Metab. 1981;53:1105-9.

17. Murray TM, Rao LG, Muzaffar SA. Dexamethasone-treated ROS $17 / 2.8$ rat osteosarcoma cells are responsive to human carboxylterminal parathyroid hormone peptide hPTH (53-84): stimulation of alkaline phosphatase. CalcifTissue Int. 1991;49(2):120-3.

18. Banerjee S, Selim H, Suliman G, Geller Al, Jüppner H, Bringhurst $F R$, et al. Synthesis and characterization of novel biotinylated carboxyl-terminal parathyroid hormone peptides that specifically crosslink to CPTH-receptor. Peptides. 2006;27(12):3352-62.

19. Selim AA, Mahon M, Juppner H, Bringhurst FR, Divieti P. Role of calcium channels in carboxyl-terminal parathyroid hormone receptor signaling. Am J Physiol Cell Physiol. 2006;291(1):C114-21.

20. Kunii IS, Vieira JGH. Circulating forms of parathyroid hormone detected with an immunofluorometric assay in patients with primary hyperparathyroidism and in hyperparathyroidism secondary to chronic renal failure. Braz J Med Biol Res. 2001;34(12):1547-50.

21. Brossard JH, Yamamoto LN, D'Amour P. Parathyroid hormone metabolites in renal failure: bioactivity and clinical implications. Seminars in Dialysis. 2002;15(3):196-201.

22. Friedman PA, Goodman WG. PTH(1-84)/PTH(7-84): a balance of power. Am J Physiol Renal Physiol. 2006;290(5):F975-84.

23. Zhang C-X, Weber BV, Thammavong J, GroverTA, Wells DS. Identification of carboxyl-terminal peptide fragments of parathyroid hormone in human plasma at low-picomolar levels by mass spectrometry. Anal Chem. 2006;78(5):1636-43. 